\title{
Analysis of Economic Value Added and Market Value Added to Measure Financial Performance in Pulp and Paper Companies
}

\author{
Wahab Edi Saputra ${ }^{1}$,Agus Sukoco ${ }^{2}$, Joko Suyono ${ }^{3}$ Damasari Ratnasahara Elisabeth ${ }^{4}$ \\ Departement of Management, Faculty Economics and Business ${ }^{1}$, Narotama University ${ }^{2}$, \\ Sekolah Tinggi Ilmu Ekonomi Mahardika,Departement Of Management ${ }^{3}$,Surabaya,Indonesia. ${ }^{4}$ \\ wahabedisaputra@gmail.com ${ }^{1}$, agus.sukoco@narotama.ac.id², joko.suyono@narotama.ac.id ${ }^{3}$
}

\begin{abstract}
Purpose: The purpose of this study was to determine the company's financial performance in the pulp and paper industry which was measured using the concept of Economic Value Added (EVA) and Market Value Added (MVA) during the period 2017 and 2018.

Design/methodology/approach: Research data is obtained through related websites and literature review.

Findings: The results of the measurement of EVA and MVA for the period 2017 and 2018 show only PT.Alkindo Naratama, Tbk. which adds to the economic value of the company and market value added (>0).

Research limitations/implications: The population in this study consisted of all pulp and paper companies that had go public and be listed on the Indonesia Stock Exchange (IDX), which is as many as nine companies, then do the purposive sampling selection which obtained a sample of four companies.

Practical implications: While three companies, namely PT. Kedawung Setia Industrial, Tbk. PT.Suparma, Tbk. and PT. Kertas Basuki Rachmat, Tbk. experience instability in EVA and MVA.

Originality/value:
\end{abstract}

Paper type: This paper can be categorized as case study paper.

Keywords: Economic Value Added (EVA), Market Value Added (MVA), FinancialPerformance

Received : June $10^{\text {th }} 2019$

Revised : July $17^{\text {th }} 2019$

Published : September $30^{\text {th }} 2019$

\section{INTRODUCTION}

The Pulp and Paper Industry is an industry that has an important role in supporting the Indonesian economy. The Pulp and Paper industry products have a very large role in Indonesia's economic development, not only providing employment but also as a potential foreign exchange contributor to the state in the non-oil and gas sector. Along with the development of the Pulp and Paper Industry and the tight competition in the industry, along with the global issues regarding social and environment that are the focus of the industry are considered to affect the performance of this industry. Namely, companies in this industry have low asset productivity so that they have the potential to not add value to the company. The low productivity of assets will have an impact on the process of adding value in the company, where the creation of adding value is very important to be a good concentration of the company. Under these conditions the company is required to conduct an assessment in advance for several periods which will provide an overview of the financial performance and future prospects.

There are several ways that are used to measure and predict financial performance, but the identical measurement concept used today is with various financial ratios. But measurements that have not taken into account the element of the cost of own capital on the profits generated will result in the report not showing actual profits, because to calculate real profits the company must calculate the cost of capital both its own capital and capital financed from debt. The dissatisfaction of this measurement, prompted Joel M Stern and G Bannet Stewart III of a consulting company in America, namely Stern Stewart \& Co in the early 1990s to develop a new measurement method or tool in conducting performance appraisal of a company based on the concept added value. This method is known as Economic Value Added which is abbreviated as EVA and Market Value Added, which is abbreviated as MVA.

Based on the background described above, the problem that will be examined in this study can be determined namely: 
How the financial performance of the Pulp and Paper companies listed on the Indonesia Stock Exchange in the period 2017 and 2018 using EVA (Economic Value Added) and MVA (Market Value Added) analysis?

\section{A. LITERATURE REVIEW}

\section{Analysis of Financial Performance}

According to Bastian (2006: 274) Performance is an overview of the achievement of the program / policy / policy in realizing the goals, objectives, mission and vision of an organization. And the concept of financial performance according to Bastian (2006) is a series of financial activities in a given period reported in financial statements including income statements and balance sheets.From this it can be concluded that the assessment of financial performance is an important benchmark to be communicated to interested parties so that they can see the prospects, growth, and potential development of the company which can then be identified actions that need to be taken to ensure the achievement of corporate objectives . A company can be said to succeed if it has reached the set standards and objectives.Financial performance needs to be evaluated through a comparison analysis between performance and targets planned by management, so that it can be known to what extent the company's success in managing the company's finances to generate profits.

\section{Method of Economic Value Added (EVA)}

According to Van Horne (2007) EVA is the net operating profit after the Net Operating Profit After Tax (NOPAT) tax minus the cost of the capital cost for capital used. While according to Tunggal (2008) EVA is a financial management system to measure economic profit in a company, which states that welfare can be created if the company is able to meet operating costs and cost of capital. In EVA there are several differences with other performance measurement methods, namely that the EVA method provides a good measurement system to assess a company's management performance and financial performance because EVA provides consideration in terms of capital costs as compensation for the funds used to finance the investment. According to Sartono (2001) EVA provides a better measurement of the added value the company provides to shareholders. Sartono's opinion is supported and made clear by O'Byrne (2001) that EVA is an effective communication tool both for value creation that can be reached by managers who ultimately encourage company performance and to connect with the capital market.

According to Tunggal (2008: 350) there are several ways and stages in calculating EVA:

\section{Calculating Net Operating Profit After Tax (NOPAT)}

NOPAT is profits derived from the operations of a company after deducting income tax, but includes financial costs (non-financial bookkeeping entries) such as depreciation costs. Sources of NOPAT calculations are in the Income Statement. NOPAT can be formulated:

$$
\text { NOPAT = Business profit (loss) - Tax }
$$

\section{Identifying Invested Capital}

Invested Capital is the sum of all corporate loans excluding interest-free short-term loans (non-interest bearing liabilities), such as trade payables, accrued expenses, tax debts, and advances. The source of the calculation of Invested Capital is in the Balance Sheet. Invested Capital can be formulated:

Invested Capital = Total Liabilities and Equity - Short-term Liabilities

\section{Determine the Weight Average Cost of Capital (WACC)}

Weight Average Cost of Capital is the minimum return on investment to get Required Rate of Return (the rate of return expected by investors or creditors and shareholders), the cost of capital in a company depends not only on the cost of debt and equity financing, but also how much of each -one is owned in the capital structure. The source of the Invested Capital calculation is in the Balance Sheet and Historical stock. This relationship is related to the Weight Average Cost of Capital of the company. calculate WACC can be calculated by the formula:

Information:

$$
\text { WACC }=\{(\mathrm{D} \times \mathrm{Rd}) \times(1-\mathrm{Tax})+(\mathrm{E} \times \mathrm{Re})\}
$$




$$
\begin{array}{ll}
\mathrm{D} & =\text { Capital level } \\
\mathrm{Rd} & =\text { Cost of debt } \\
\mathrm{Tax} & =\text { Tax rate } \\
\mathrm{E} & =\text { Capital Level and Equity } \\
\mathrm{Re} & =\text { Cost of equity }
\end{array}
$$

\section{Calculating Capital Charges}

Capital Charges or in Indonesian capital charges are real costs that must be issued by the company to obtain funds, both from debt, shares, and retained earnings to fund an investment or company activities. How to calculate Capital Charges is:

$$
\text { Capital Charges }=\text { WACC } \times \text { Invested Capital }
$$

\section{Calculating Economic Value Added (EVA)}

Calculating EVA can be done by the formula:

$$
\mathrm{EVA}=\mathrm{NOPAT}-\text { Capital Charges }
$$

All of these methods make it easier for those in need in assessing financial performance. Regardless of how to calculate EVA above, what needs to be considered for an investor is the wisdom in choosing profitable investments, namely investments with optimum returns and minimum risks, so as to create added value economical for the company.

From the EVA formula above, Wiweko (2014) makes parameters about the use of EVA by knowing whether there is an addition to the value of a company's financial performance with the following conditions:

- EVA>0

This shows that the company's financial performance can be said to be good, because the company can add business value. Based on this, the employee has the right to get a bonus, the creditor still gets interest and the shareholder can get the same or more returns from the original planted.

\section{- $\mathrm{EVA}=0$}

This shows that it is economically "break-even" because all profits are used to pay obligations to persons and creditors and shareholders, so that employees don't get only salary bonuses.

- EVA $<0$

This shows that the company's financial performance is said to be unhealthy because the company can't provide added value, in this case the employee can't get a bonus, but the creditor still gets interest and the shareholder doesn't get a return commensurate with the planted.

\section{Benefits of Economic Value Added (EVA)}

According to Tunggal (2008) the benefits obtained by using EVA are:

1. EVA is a measure of company performance that can stand alone without requiring another measure in the form of a comparison using similar companies or analyzing trends (trends).

2. The results of the EVA calculation encourage the allocation of funds companies for investment with low capital costs.

\section{Weaknesses and Strengths of Economic Value Added (EVA)}

According to Fauzan (2012) the advantages of using EVA are:

1. The EVA concept is a company tool in measuring expectationsseen from an economic point of view, namely by paying attention to the expectations of funders fairly where the degree of justice is expressed by a weighted measure of the existing capital structure and guided by market value and not on book value.

2. EVA focuses on valuation with added valuetake into account the burden as a consequence of investment.

3. Calculation of EVA can be used independently withoutrequires comparative data such as industry standards or other company data as the concept of valuation.

4. The EVA concept can be used as the basis for evaluating bonuses for employees, especially in divisions that provide more EVA so that it can be said that EVA runs stakeholders satisfaction concepts.

5. Easy application of EVA shows that the concept is a practical measure, easy to calculate and easy to use so that it is one of the considerations in accelerating business decision making. 
According to Tunggal (2008) there are several weaknesses in the use of EVA in measuring financial performance, namely:

1. EVA only creates value in certain years

2. Practically EVA isn't necessarily easy to apply.

3. The EVA calculation process requires an estimate of the cost of capital and this estimateespecially forcompanies Go Public is difficult.

Method Market Value Added (MVA)

According to Brigham and Houston $(2010,111)$ MVA is the difference between market value of equity and book value. Whereas according to Winarto (2010.4) MVA is the difference between capital invested in the company all the time to profit. MVA is a measure used to measure success in maximizing the wealth of shareholders by allocating appropriate sources.

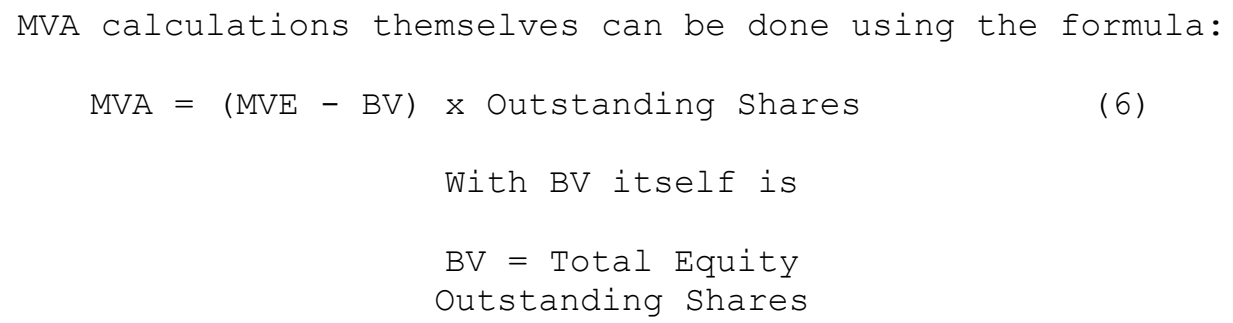

Information:

MVE

BV

$=$ Stock market price (Market value equity)

Outstanding Shares

$=$ Book value of shares (book value of equity)

$=$ Number of outstanding shares

Market Value and Outstanding Shares can be seen from historical data shares on the Indonesia Stock Exchange (IDX), while Book Value (BV) can be found in the Balance Sheet report.

From the formula above Abu Bakar (2010) it can be interesting to conclude that:

- $\quad$ MVA>0

This shows the management has successfully sold the company's shares at the market at a premium price.

- $\quad \mathrm{MVA}=0$

This shows that management is not successful in providing added value and reduction through the growth of market capitalization value of shares because the stock price in the market is the sameas the book value.

- $\quad$ MVA $<0$

This shows that management is not able to provide added value and a reduction through the growth of market capitalization value of shares issued or the price of shares in the market belowthe book value.

\section{Benefits of Market Value Added (MVA)}

According to Wiweko (2014) the benefits of Market Value Added (MVA) are:

1. As a tool to measure added value from the company improve the welfare of shareholders.

2. With MVA investors can take anticipatory actions before taking Investation decision.

3. MVA can be used as a measuring tool or improvement assessment the wealth of thecompany's shareholders.

\section{Weaknesses and Strengths of Market Value Added (MVA)}

According to Zaky and Ary (2012: 139) excess use of Market Value Added (MVA) is a single measure and can stand itself which does not require analysis of trends or industry norms so that management and fund providers will find it easier in assessing company performance.

According to Agustin (2014) there are some disadvantages in using the MVA method to measure financial performance, namely:

1. MVA is a periodic measure of shareholders' wealth so that it can't measure performance at the division level.

2. MVA is a certain period doesn't provide an improvement solution the creation of shareholder wealth.

Analysis Of Economic Value Added And Market Value Added To Measure Financial Performance In Pulp And Paper 
3. MVA ignores the opportunity for capital invested in the company.Measurement of MVA fails to take into account past cash to shareholders.

\section{Relationship between Economic Value Added (EVA) and Market Value Added (MVA)}

Considering O'Byrne's and Stewart's research, the MVA is dependent on EVA. This means that stock market prices reflect all information available on the capital market, or stock market prices in the capital market reflect the company's internal performance. There is a significant relationship between EVA and MVA.

\section{Framework For Concepts}

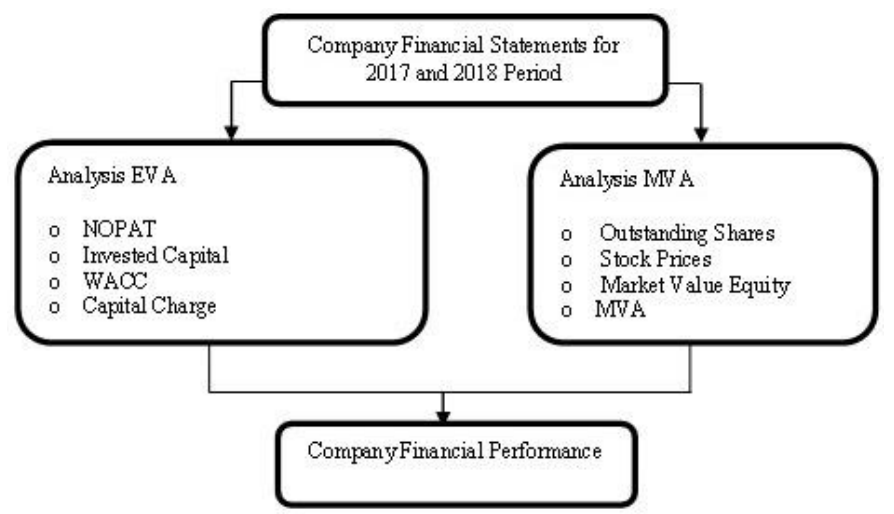

Figure 1: Research Model

\section{METHODS}

\section{Research Approach}

Judging from its purpose, this study uses the Analytical Descriptive approach with qualitative methods. The purpose of this study is to provide conclusions used in decision making.

\section{Data Types}

The type of data used in this research is secondary data. That is, financial report data is taken from the company's web as research.

\section{Population}

Population is a group of people, events or symptoms of something that has certain characteristics (Muis and Priadana, 2009). The population used in this study are all companies in the pulp and paper industry that go public on the Indonesia Stock Exchange (IDX), which are nine companies.

\section{Sample}

Samples are part of a population that is taken or determined based on certain techniques and characteristics (Wijaya, 2013). The method used in the selection of this research sample is purposive sampling, the sample is obtained using the following criteria:

- The company is engaged in the pulp and paper industry that is listed on the IDX and the company's shares are actively traded in the capital market.

- The company has been listed on the IDX before the research period.

- The company in presenting financial statements must be in Rupiah, so that refraction does not occur in the analysis.

After screening based on the above criteria, the samples obtained in this study are as follows:

Tabel 1: All Study Samples

Analysis Of Economic Value Added And Market Value Added To Measure Financial Performance In Pulp And Paper Companies 


\begin{tabular}{|l|c|}
\hline \multicolumn{1}{|c|}{ Description } & Total \\
\hline $\begin{array}{l}\text { The company is engaged in the pulp and paper industry listed on the IDX and the } \\
\text { company's shares are actively traded in the capital market. } \\
\text { The company in presenting the financial statements must be in Rupiah, so that } \\
\text { refraction doesn't occur in the analysis. } \\
\text { The company has been listed on the IDX before the research period. }\end{array}$ & 5 \\
& 4 \\
\hline
\end{tabular}

Of the nine population, there are five companies that do not meet the requirements or criteria of researchers. There are five companies which in the study period left the listing on the Indonesia Stock Exchange (IDX) and the four companies in their financial statements used the value of US Dollar.Based on the sampling stage, there are four companies sampled in this study, namely:

Tabel 2: Study Samples

\begin{tabular}{|l|l|l|}
\hline No & \multicolumn{1}{|c|}{ Code Compay } & \multicolumn{1}{c|}{ Company } \\
\hline 1 & SPMA & PT. Suparma, Tbk \\
2 & KBRI & PT. KertasBasukiRachmat, Tbk. \\
3 & KDSI & PT. KedawungSetia Industrial, Tbk. \\
4 & ALDO & PT. AlkindoNaratama, Tbk. \\
\hline
\end{tabular}

\section{Withdrawal Conclusion}

Conclusions in qualitative research may be able to answer the formulation of the problem formulated from the beginning, but also not, because problems and formulation of problems in qualitative research are still temporary and develop after researchers begin research previously unclear becomes clear.

\section{RESULTS AND DISCUSSION}

\section{Data Analysis}

In this study researchers used descriptive qualitative research analysis techniques, because researchers wanted to explain the facts of several financial statements by presenting data with qualitative methods in the form of tables and narative texts.

\section{Calculation Results of EVA Value for Pulp and Paper Companies}

Table 3: Results of EVA Value Calculation 2017 (Based on Ranking)

\begin{tabular}{|l|c|c|c|}
\hline \multicolumn{1}{|c|}{ Company } & $\begin{array}{c}\text { NOPAT } \\
\text { (a) }\end{array}$ & $\begin{array}{c}\text { Capital Charge } \\
\text { (b) }\end{array}$ & $\begin{array}{c}\text { EVA Value } \\
(\mathbf{a}-\mathbf{b})\end{array}$ \\
\hline PT. Kedawung Setia Industrial, & $68,965,208,549$ & $45,143,794,658.177$ & $24,750,298,554.571$ \\
Tbk. & $92,280,117,234$ & $81,852,473,723$ & $10,427,643,511$ \\
PT.Suparma, Tbk. & $29,035,395,397$ & $21,199,328,393.719$ & $7,836,067,003.281$ \\
PT. Alkindo Naratama, Tbk & $87,413,921,829$ & $121,826,919,451.68$ & $-19,312,602,144.42$ \\
PT. Kertas Basuki Rachmat, Tbk.
\end{tabular}

From table 1 above, it can be seen that the EVA value in the 2017 Pulp And Paper company in general can be said to be good $(>0)$ in adding company value. There are three companies that are able to add value to their company, namely from the highest there is PT. Kedawung Setia Industrial, Tbk. amounting to 24,750,298,554,571. PT.Suparma, Tbk. amounting to 10,427,643,511 and PT.Alkindo Naratama, Tbk. amounting to $7,836,067,003,281$. While there is one company that is not able to add value to the company $(<0)$, namely PT. Kertas Basuki Rachmat, Tbk. amounting to $-19,312,602,144.42$. Factors that make PT. Kedawung Setia Industrial, Tbk. because this company has a high net profit value while its expenditure costs are low. Unlike PT. Suparma, Tbk. who have the highest net income but also high expenditure costs. Whereas PT. Kertas Basuki Rachmat, Tbk. have higher expenditure than net income.

Table 4: EVA Value Calculation Results for 2018 (Based on Ranking)

\begin{tabular}{|c|c|c|c|}
\hline Company & $\begin{array}{c}\text { NOPAT } \\
\text { (a) }\end{array}$ & $\begin{array}{c}\text { Capital Charge } \\
\text { (b) }\end{array}$ & $\begin{array}{c}\text { EVA Value } \\
(\mathbf{a}-\mathbf{b})\end{array}$ \\
\hline
\end{tabular}

Analysis Of Economic Value Added And Market Value Added To Measure Financial Performance In Pulp And Paper 


\begin{tabular}{l|c|c|c} 
PT. Kedawung Setia Industrial, & $76,761,902,211$ & $50,596,148,092.647$ & $26,165,754,118.353$ \\
Tbk & $42,506,275,523$ & $33,534,074,032.283$ & $8,972,201,490.615$ \\
PT. Alkindo Naratama, Tbk & $82,232,722,269$ & $99,558,378,648.418$ & $-17,325,656,379.41$ \\
PT.Suparma, Tbk. & $108,023,778,501$ & $408,123,796,383.59$ & $-297,045,372,698.86$ \\
PT. Kertas Basuki Rachmat, Tbk
\end{tabular}

The EVA value of the 2018 Pulp And Paper company isn't much different from 2017, but PT. Suparma, Tbk. which in 2017 has an EVA value of 10,427,643,511 but in 2018 PT. This isn't able to add to the value of the company instead it tends to decrease to $-17,325,656,379.41(<0)$, this is because the net profit after tax (NOPAT) of PT. Suparma, Tbk. in 2018 it decreased.

\section{Calculation Result of MVA Value for Pulp and Paper Companies}

Table 5: Results of MVA Value Calculation 2017 (Based on Ranking)

\begin{tabular}{|l|l|l|c|c|c|c|}
\hline No & Company & $\begin{array}{l}\text { Market } \\
\text { Value } \\
(\mathbf{a})\end{array}$ & $\begin{array}{c}\text { Outstanding } \\
\text { Shares } \\
(\mathbf{b})\end{array}$ & $\begin{array}{c}\text { Value Of The } \\
\text { Company } \\
\mathbf{c = ( a x b )}\end{array}$ & $\begin{array}{c}\text { Invested Capital (IC) } \\
(\mathbf{d})\end{array}$ & $\begin{array}{c}\text { MVA Value } \\
\text { (c }-\mathbf{d})\end{array}$ \\
\hline 1 & $\begin{array}{l}\text { PT. Alkindo Naratama, } \\
\text { Tbk }\end{array}$ & 600 & $550,000,000$ & $330,000,000,000$ & $256,035,395,395.387$ & $73,964,604,603$ \\
2 & $\begin{array}{l}\text { PT. Kedawung Setia } \\
\text { Industrial, Tbk }\end{array}$ & 550 & $405,000,000$ & $434,399,786,700$ & $256,035,395,397$ & $-33,285,395,397$ \\
4 & $\begin{array}{l}\text { PT. Kertas Basuki } \\
\text { Rachmat, Tbk }\end{array}$ & 50 & $8,687,995,734$ & $222,750,000,000$ & $853,129,688,037$ & $-418,734,901,337$ \\
PT.Suparma, Tbk. & 270 & $2,114,570,958$ & $570,934,158,660$ & $1,418,587,066,269$ & $-847,652,907,609$ \\
\hline
\end{tabular}

Companies that are able to create wealth for company owners in 2017 are PT. Alkindo Naratama, Tbk. amounting to $73,964,604,603$ (> 0) while other companies still can't create wealth for company owners $(<0)$.

Table 6: Results of MVA Value Calculation in 2018 (Based on Ranking)

\begin{tabular}{|c|c|c|c|c|c|c|}
\hline No & Company & $\begin{array}{l}\text { Market } \\
\text { Value } \\
\text { (a) }\end{array}$ & $\begin{array}{c}\text { Outstanding } \\
\text { Shares } \\
\text { (b) }\end{array}$ & $\begin{array}{c}\text { Value Of The } \\
\text { Company } \\
\text { c =(axb) }\end{array}$ & $\begin{array}{c}\text { Invested Capital (IC) } \\
\text { (d) }\end{array}$ & $\begin{array}{l}\text { MVA Value } \\
(\mathbf{c}-\mathrm{d})\end{array}$ \\
\hline 1 & $\begin{array}{l}\text { PT. Alkindo Naratama, } \\
\text { Tbk }\end{array}$ & 670 & $550,000,000$ & $368,500,000,000$ & $294,824,481,262$ & $73,824,481,262$ \\
\hline 2 & $\begin{array}{l}\text { PT. Kertas Basuki } \\
\text { Rachmat, Tbk }\end{array}$ & 50 & $8,687,995,734$ & $434,399,786,700$ & $386,663,947,308$ & $47,735,839,392$ \\
\hline 3 & $\begin{array}{l}\text { PT. Kedawung Setia } \\
\text { Industrial, Tbk }\end{array}$ & 1.000 & $405,000,000$ & $405,000,000,000$ & $685,584,662,502$ & $-280,584,662,502$ \\
\hline 4 & PT.Suparma, Tbk. & 103 & $2,114,570,958$ & $217,800,808,674$ & $2,031,803,808,674$ & $-1,814,002,837,212$ \\
\hline
\end{tabular}

PT. Alkindo Naratama, Tbk in 2018 is still able to create wealth for the owner of the company (>0) despite falling from the previous year. But significant changes occurred at PT. Kertas Basuki Rachmat, Tbk which in 2018 was able to create wealth for shareholders. For PT. Kedawung Setia Industrial, Tbk and PT.Suparma, Tbk in 2018, it is still unable to create wealth for shareholders $(<0)$ and even tends to decline compared to 2017.

\section{Relationship Between EVA and MVA}

From the results of the EVA and MVA analysis, it can be seen that PT. Alkindo Naratama, Tbk is the best company in providing added value, both for companies and shareholders. One of the factors is that this company has a good level of Invested Capital or in other words has good financial performance. While the other three companies,PT.Suparma Tbk, PT. Kertas Basuki Rachmat Tbk, PT. Kedawung Setia Industrial Tbk, tend to be unstable, they are good at providing added value to the company but not so good to the shareholders.

\section{CONCLUSION}

1. Judging from the EVA approach, it is known that in 2017 there are three companies namely PT. Kedawung Setia Industrial, Tbk. PT.Suparma, Tbk. and PT. Alkindo Naratama, Tbk is positive (>0).

Analysis Of Economic Value Added And Market Value Added To Measure Financial Performance In Pulp And Paper 
This means that the three companies in 2017 were able to add economic value to that period. And there is one company, namely PT. Kertas Basuki Rachmat, Tbk. negative $(<0)$. This means that the company isn't able to add economic value in that period. Whereas in 2018 there were a number of changes, namely at PT.Suparma, Tbk. in 2018 the company experienced a decline in performance in adding to its economic value. Which in the previous year was positive, but in 2018 it was negative.

2. Judging from the MVA approach, it is known that in 2017 there is only one company that has a positive value $(>0)$, namely PT. Alkindo Naratama, Tbk and three other companies are negative $(<0)$. This means that only PT. Alkindo Naratama, Tbk, which is able to increase the value of shareholders' capital. Whereas the other three companies were unable to increase the value of shareholders' capital.

3. The results of the measurement of EVA and MVA for the period 2017 and 2018 show only PT.Alkindo Naratama, Tbk. which adds to the economic value of the company and market value added (>0). While three companies, namely PT. Kedawung Setia Industrial, Tbk. PT.Suparma, Tbk. and PT. Kertas Basuki Rachmat, Tbk. experience instability in EVA and MVA.

\section{REFERENCES}

Arikunto, S. (2002). Prosedur Penelitian. Jakarta : Rineka Cipta. Prosedur Penelitian. Jakarta : Rineka Cipta. Bakar, A. (2010). Analisis Perbandingan Kinerja Perusahaan Telekomunikasi Dengan Menggunakan Eva, Reva, Fva, Dan Mva. Jurnal Rekayasa Institut Teknologi Nasional.Lppm Itenas, X Iv, 19-27.

Bastian, I. (2006). Akuntansi Sektor Publik: Suatu Pengantar. Jakarta: Erlangga.

Brigham, H. Dan. (2001). Manajemen Keuangan. (8th Ed.). Jakarta: Erlangga.

Butarbutar, L. (2017). Analisis Kinerja Keuangan Menggunakan Pendekatan Economic Value Added (Eva) Dan Market Value Added (Mva) Pada Perusahaan Bumn Sektor Pertambangan Yang Terdaftar Di Bei Periode 2011-2015.

Fauzan, M. S. (2012). Analisis Kinerja Keuangan Dengan Menggunakan Metode Eva (Economic Value Added) Pada Pt. Raja Tirta Jaya Di Makassar. Skripsi. Fakultas Ekonomi Dan Bisnis Universitas Hasanuddin.

Harahap, S. S. (2001). Analisa Kritis Atas Laporan Keuangan (Edisi Satu). Jakarta : Pt Raja Grafindo Persada.

Kim, W. G. (2006). Eva And Traditional Accounting Measures: Which Metric Is A Better Predictor Of Market Value Of Hospitality Companies?

Luh Putu Ayu Purnami, F. Y., \& Yulianthini, N. N. (2016). Kinerja Keuangan Menggunakan Pendekatan Economic Value Added (Eva) Dan Market Value Added (Mva) Pada Bank Bumn.

Maheni Ika Sari, B. W. (2018). Mengukur Kinerja Keuangan Dengan Eva Dan Mva.

Muhammad Ridho Firdausi, Dadan Rahadian, A. S. D. (2017). Analisis Kinerja Keuangan Dengan Menggunakan Metode Economic Value Added (Eva), Financial Value Added (Fva) Dan Market Value Added (Mva) Studi Kasus Pada Operator Telekomunikasi Yang Terdaftar Di Bei Periode 2008-2015.

Muis, P. Dan. (2009). Metodologi Ekonomi Dan Bisnis. Yogyakarta: Graha Ilmu.

O’byrne, Y. \&. (2001). Eva Dan Manajemen Berdasarkan Nilai (1st Ed.). Jakarta: Salemba Empat.

Okaberina Pratiwi, U. (2017). Analisis Kinerja Keuangan Perusahaan Pulp Dan Kertas Yang Go Public Di Bursa Efek Indonesia (Bei) Berdasarkan Metode Economic Value Added (Eva), Market Value Added (Mva) Dan Return On Asset (Roa) Periode 2011-2015.

Saeid Jabbarzadeh Kangarloei , Morteza Motavassel, E. A. And B. S. (2012). The Investigation Of The Relationship Between Economic Value Added (Eva) And Return On Assets (Roa) In Tehran Stock Exchange (Tse).

Sartono, A. (2001). Manajemen Keuangan Teori Dan Aplikasi. Yogyakarta: Agus Sartono, 2001. Manajemen Keuangan Teori Dan Aplikasi. Yogyakarta: Bpef-Yogyakarta.

Sharma, A. K. (2012). Eva Versus Convenational Performance Measures - Empirical Evidence From India.

Tunggal. (2008a). Analisis Penilaian Kinerja Keuangan Menggunakan Penerapan Economic Value Added.

Tunggal, A. W. (2008b). Dasar - Dasar Customer Relationship Management (Crm). Jakarta: Harvindo.

Van Horne, J. C. And J. M. W. (2007). Fundamentals Of Financial Management, Prinsip-Prinsip Manajemen Keuangan. Jakarta: Salemba Empat.

Wet, J. H. Vh. De. (2012). Executive Compensation And The Eva And Mva Performance Of South African Listed Companies.

Wet, Jh. De. (2005). Eva Versus Traditional Accounting Measures Of Performance As Drivers Of Shareholder Value - A Comparative Analysis.

Winarto. (2010). Tagetes Berguna Bagi Kita. Deptan. Sumatera Utara: Bptp.

Wiweko, H. (2014). Penilaian Kinerja Keuangan Perusahaan Dengan Metode Rasio Keuangan, Economic Value

Analysis Of Economic Value Added And Market Value Added To Measure Financial Performance In Pulp And Paper

Companies

Wahab Edi Saputra1,Agus Sukoco2, Joko Suyono3 Damasari Ratnasahara Elisabeth4 
Added (Eva) Dan Market Value Added (Mva) (Studi Kasus : Sektor Farmasi Di Bursa Efek Indonesia), $11,86-100$. 